\title{
Seed weight of Xylopia aromatica (Annonaceae): quality evaluation from X-ray and seedling emergence
}

\author{
Fábio Socolowski ${ }^{1}$, Silvio Moure Cicero ${ }^{2 *}$, Daniela Cristine Mascia Vieira ${ }^{3}$ \\ ${ }^{1}$ USP/ESALQ - Programa de Pós-Gradução em Fitotecnia. \\ ${ }^{2}$ USP/ESALQ - Depto. de Produção Vegetal, C.P. 09 - 13418-900 - Piracicaba, SP - Brasil. \\ ${ }^{3}$ UNESP - Depto de Botânica, Av. 24 A, 1515 - 13506-900 - Rio Claro, SP - Brasil. \\ *Corresponding author 〈smcicero@esalq.usp.br> \\ Edited by: Luís Reynaldo Ferracciú Alleoni
}

\begin{abstract}
Xylopia aromatica (Lam.) Mart. (Annonaceae) is a native species of the Brazilian Savannah ("Cerrado") region, recommended for the recovery of degraded areas and also for medicinal use. Seeds of some species of the Annonaceae require a long period to germinate and many studies have focused on determining methods which can rapidly analyze seed quality. The objective of this study was to evaluate the quality of Xylopia aromatica (Lam.) Mart. seeds in accordance to their weight, through X-ray images and emergence test. Seeds were collected from dehiscent follicles with a blower and one portion was separated into weight categories: very light seeds, light seeds and heavy seeds. Another seed portion was separated in water by their density, into those that sank and those that floated. The seeds from each weight category were weighed and X-rayed. A further seed portion from the categories (separated by blower and in water) was also placed in 500 $\mathrm{mg} \mathrm{L}^{-1}$ of a solution [gibberellin $4\left(\mathrm{GA}_{4}\right)+$ gibberellin $7\left(\mathrm{GA}_{7}\right)$ and cytocinin] to overcome dormancy and was later sown in soil taken from the "Cerrado". The internal seed morphology and seedling emergence of $X$. aromatica were influenced by seed weight. The elimination of badly formed and insect- infested seeds improved the physiological potential of the seed lot. The X-ray test can efficiently evaluate seed quality but does not permit a visualization of the embryos.

Keywords: Brazilian Savannah, seed processing, internal morphology, forestry seed
\end{abstract}

\section{Introduction}

In the last few years, interest in the propagation of native forest species has increased due to the present emphasis on environmental issues (Araújo Neto et al., 2003). The demand for seeds and seedlings of native species has encouraged research in these areas (Santos and Aguiar, 2000), resulting in the availability of good quality seed for environmental recovery projects (Bonner, 1992).

Heavy seeds present greater germination capacity because they are well formed and less damaged (Socolowski and Cicero, 2008). The nutrient reserves of seeds influence germination, growth and seedling survival (Khan and Shankar, 2001), resulting in a higher seedling competiveness of heavy seeds (Upadhaya et al., 2007; Santos et al., 2009). Therefore, higher seed reserves increase the probability of successful seedling establishment (Haig and Westoby, 1991; Khan, 2004).

Most forest species need a long period to germinate and, therefore, there is a need to develop quick and efficient tests to evaluate seed quality (Piña-Rodrigues and Santos, 1988). Among tests considered as rapid is the $\mathrm{X}$-ray, which has been used in Brazil to evaluate seed quality of forest species (Machado and Cicero, 2003; Mondo et al., 2008; Pupim et al., 2008; Socolowski and Cícero, 2008). This test allows an insight about the physical and physiological quality of seeds that influence the germination (Tonetti et al., 2006).

Xylopia aromatica seeds have embryos with morphophysiological dormancy (Sautu et al., 2007). It is a species that was included in the list of plants threatened by extinction (Maroni et al., 2006) and has been recommended in the Resolution SMA 47/2003 (São Paulo state law) for the recuperation of degraded "Cerrado" areas. The objective of this study was to evaluate the quality of Xylopia aromatica (Lam.) Mart. seeds in accordance to their weight through $\mathrm{X}$-ray images and germination test.

\section{Materials and Methods}

$X$ aromatica seeds were collected in April 2009 from mature

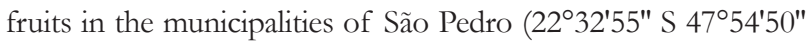
W) and Itirapina $\left(22^{\circ} 15^{\prime} 10^{\prime \prime} \mathrm{S} 47^{\circ} 49^{\prime} 22^{\prime \prime} \mathrm{W}\right)$, São Paulo State, Brazil and were treated as a single set. They were washed in running water, inside a cloth bag, until the arils and sarcotesta were removed. A portion of the collected seeds was separated into three weight categories by ventilating twice for 3 mins each time, using a blower (South Dakota, model 757) with a $14 \mathrm{~cm}$ opening. The very light seeds (VLS) were removed during the first ventilation and the light (LS) and heavy seeds (HS) during the second ventilation. Another collected seed portion was separated in water by density into those which floated (F) and those which sank (S).

Seeds were then separated into four replications of 25 seeds, for each one of the weight categories, which were weighed on a precision balance $(0.0001 \mathrm{~g})$. They were also numbered and individualized only to obtain weight and radiograph. Following this, the seeds were distributed into the cells of an acrylic plate and X-rayed with a Faxitron X Ray MX - 20. The images were obtained using a X-ray film Kodak MIN-R EV 2000, measuring $18 \times 24 \mathrm{~cm}$, at a distance of $40 \mathrm{~cm}$ from the radiation source, at an intensity of $13 \mathrm{kV}$ for 350 seconds.

Based on the X-ray images, the seeds were classified into undamaged seeds (US), those where no morphological damage was detected (white color seeds), and damaged seeds (DS), those where the internal seed space was unfilled (empty seeds, black in color), infested by insects or showing some other abnormality. 
The water content of the seeds for each weight category was determined using a drying oven at $105 \pm 3{ }^{\circ} \mathrm{C}$ for 24 hours (Brasil, 2009), with four replications of 25 seeds. The results were expressed as a mean percentage and calculated based on the wet weight.

Simultaneously, a hundred seeds of each of the weight categories were imbibed in solutions of a solution [gibberellin $4\left(\mathrm{GA}_{4}\right)+$ gibberellin $7\left(\mathrm{GA}_{7}\right)$ and cytocinin] at a concentration of $500 \mathrm{mg} \mathrm{L}^{-1}$ for $48 \mathrm{~h}$ at $30{ }^{\circ} \mathrm{C}$, with the aim of overcoming seed dormancy. Four replications of 25 seeds of each weight category were then separated and sown at a depth of $1 \mathrm{~cm}$ in 46 $\times 30 \mathrm{~cm}$ trays with $7.4 \mathrm{~kg}$ of soil from a "Cerrado" area, moistened up to $70 \%$ of the water retention capacity; later, they were placed under cover without any temperature control to observe seedling emergence every 48 hours over 90 days.

The percentages and speeds of seedling emergence and the formation of normal seedlings were calculated. Seedlings were considered as emerged when they broke through the substrate with $1 \mathrm{~cm}$ above the surface and were considered normal when free of the seed integument. Speed of seedling emergence and the formation of normal seedlings were calculated adjusting the equation of GSI (germination speed index) proposed by Maguire (1962), GSI $=\mathrm{G}_{1} / \mathrm{N}_{1}+\mathrm{G}_{2} / \mathrm{N}_{2}+\ldots \mathrm{G}_{\mathrm{n}} / \mathrm{N}_{\mathrm{n}}$, where $\mathrm{G}_{1}$, $\mathrm{G}_{2}, \mathrm{G}_{\mathrm{n}}$ are the number of germinated seeds, and $\mathrm{N}_{1}, \mathrm{~N}_{2}, \mathrm{~N}_{\mathrm{n}}$ the number of days.

An entirely random experimental design was adopted and the data in percentages were transformed into arc $\sin \sqrt{x / 100}$. An analysis of variance was used followed by the Least Square Difference (LSD) test at the $5 \%$ probability level (Vieira, 2006), to compare the percentages and mean speeds of the different weight categories.

\section{Results and Discussion}

The highest mean of seed weight was observed for heavy seeds $(48.7 \mathrm{mg})$. The seeds which sank weighed $41.4 \mathrm{mg}$, the light category was $40.7 \mathrm{mg}$, the very light category was $39.5 \mathrm{mg}$ and $24 \mathrm{mg}$ for those that floated, which was different from others categories (Figure 1).

The water content of each of the seed weight categories was $33.8 \%$ for those that floated, $21.5 \%$ for those that sank, $20.6 \%$ for the very light seeds, $19.3 \%$ for the light seeds and

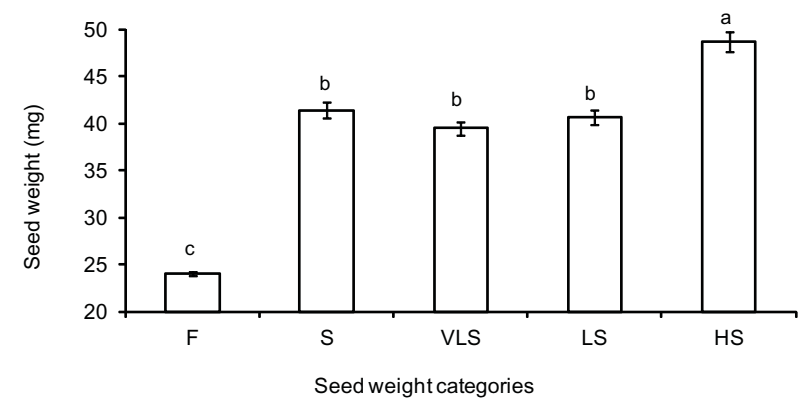

Figure 1 - Mean weight of Xylopia aromatica seeds according to each weight category. The vertical bars show the standard error. Different letters indicate differences (LSD test, $p<0.05) . \mathrm{F}=$ seeds which floated; $\mathrm{S}=$ seeds which sank; VLS = very light seeds, LS = light seeds; HS = heavy seeds.
$19.9 \%$ for the heavy seeds. The differences observed in the seed water contents of the different weight categories may be related to the applied methods.

The X-ray images showed that only $1 \%$ of the floated seeds were undamaged. The remaining weight categories had more than $80 \%$ of undamaged seeds, however the seeds which sank, light and heavy seeds presented the lowest percentage of damage (Figure 2). From X-ray images, Figure 3 illustrates two seeds which floated, one with no internal filling (empty seed) and another infested by insects, whereas Figure 4 shows X-ray images of an undamaged and a damaged seed. According to Perioto (1997), X. aromatica seeds are infested by Bephratelloides sp. (Hymenoptera: Eurytomidae) before fruit dehiscence.

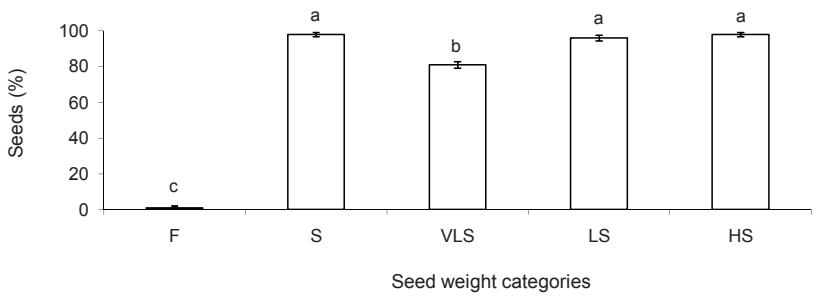

Figure 2 - Mean percentage of undamaged seeds of Xylopia aromatica according to the weight category evaluated by the $\mathrm{X}$-ray test. The vertical bars show the standard error. Different letters indicate differences (LSD test, $p<0.05$ ). F $=$ seeds which floated; $\mathrm{S}=$ seeds which sank; VLS = very light seeds; LS = light seeds; HS = heavy seeds.
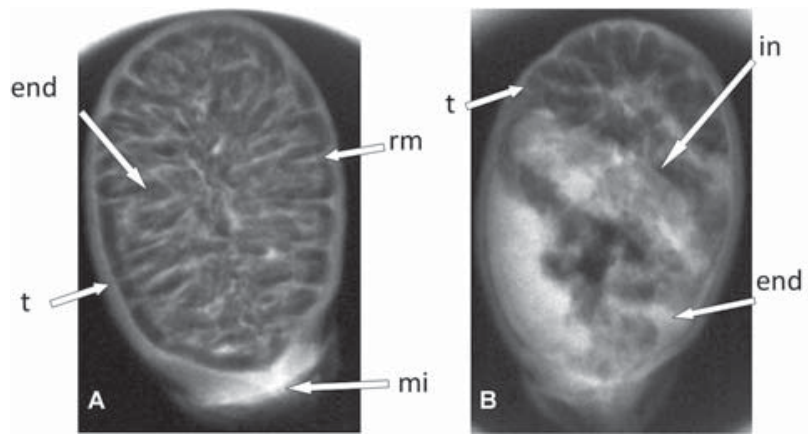

Figure 3-X-ray images of seeds of Xylopia aromatica which floated without endosperm development (A) and insect-infested (B); end = endosperm; in = insect; $\mathrm{mi}=$ micropyle; $\mathrm{rm}=$ rumination; $\mathrm{t}=$ integument.

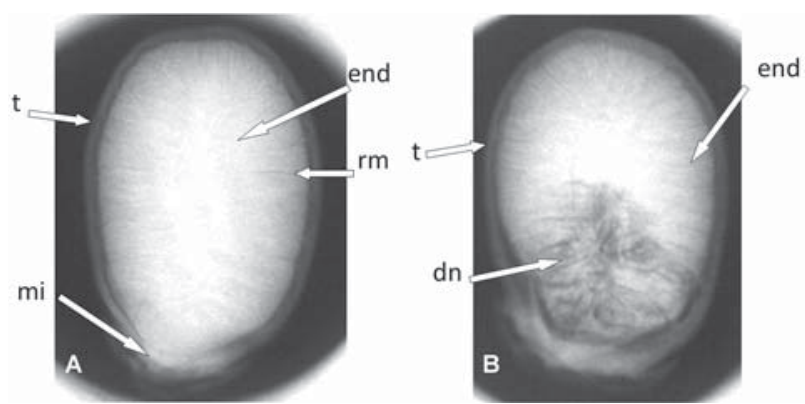

Figure 4 - X-ray images of heavy seeds of Xylopia aromatica without (A) and with damage (B) of the endosperm; dn = damage; end $=$ endosperm $; \mathrm{mi}=$ micropyle $; \mathrm{rm}=$ rumination; $\mathrm{t}=$ integument. 
The seeds of the genus Xylopia are albuminous, with a ruminate endosperm, corneous and oily, a whitish color (Castellani et al., 2001); due to these characteristics, in the present research the observed damage was present only in the endosperm. Castellani et al. (2001) reported that locating the embryo in dry Xylopia aromatica seeds was impossible and that it is 268 times smaller than its endosperm and occupies a basal, peripheral position in the seed, which is of the continuous type and little differentiated. However, Lobo et al. (2007) considered that the Annonaceae have pollination problems resulting in the formation of seeds without embryos.

The emergence of the seeds which floated was not evaluated because there were insufficient seeds available in this category to perform the test. This has also been observed in other studies using X-ray images of seeds of forest species classified as insect-infested (Souza et al., 2008) or empty (Souza et al., 2008), that they did not germinate.

The heavy seeds showed the highest percentages of emergence $(78 \%)$ and formation of normal seedlings (49\%), only showing differences with the very light seeds $(54 \%$ and 25 $\%$, respectively). The percentage of the formation of normal seedlings was less compared to the percentage of seedling emergence since some seedlings showed cotyledon necrosis after they were set free or did not finish their development, and had only the hypocotyl and root developed. Similarly, the fastest speed seedling emergence was observed for heavy seeds and the slowest for the very light seeds (Table 1).

From the results of seedling emergence and the formation of normal seedlings in each weight category, the seeds classified as undamaged (Figure 2) can produce either normal or abnormal seedlings or may not germinate. But since $X$. aromatica seeds show dormancy, some seeds may not have completed their germination process during the evaluation period or may even had damaged embryos which were not observed in the images. Also, due to natural variations, seeds showing good characteristics observed by X-ray may not germinate, probably due to infections caused by microorganisms or because they are dead (Burg et al., 1994).

The intraspecific variation of seed weight can affect not only germination (Schaal, 1980), but also the seedling characteristics, and in this way influence the recruitment of species (Hendrix, 1984). Heavier seeds have more developed endosperm or cotyledons, are richer in the energy reserves necessary for germination (Gonzalez, 1993; Moegenburg, 1996), and can also show a higher hormone level and a larger embryo (Surles et al., 1993). Thus, seedlings from larger seeds emerge faster (Parker et al., 2006), but these characteristics do not necessarily guarantee seedling survival until maturity (Susko and Lovett-Doust, 2000).

The heavier seed categories can have well-developed endosperm, which was corroborated by the strict relationship between the X-ray images and the results of the test for seedling emergence. These seeds are more vigorous and germinate in a higher proportion and at a faster rate. Therefore, it is important to improve the quality of seed lots of $X$. aromatica, with the elimination of badly formed or infested seeds using ventilation or separation in water.

\section{Conclusions}

The weight of Xylopia aromatica seeds affected the internal morphology and seedling emergence. The elimination of badly formed insect-infested seeds by ventilation or separation in water helps to improve the physiological potential of a seed batch. The X-ray test can efficiently evaluate seed quality although the images do not allow embryos to be seen.

\section{Acknowledgements}

To FAPESP, for granting a scholarship to the first author, to the Forestry Institute of São Paulo State for permission to collect seeds. To Helena M. C. P. Chamma for her support during the study.

\section{References}

Araújo Neto, J.C.; Aguiar, I.B.; Ferreira, V.M. 2003. Effect of temperature and light on Acacia polyphylla DC. Seed germination. Revista Brasileira de Botânica 26: 249-256 (in Portuguese, with abstract in English).

Bonner, F.T. 1992. Seed Technology: a challenge for tropical forestry. Tree Planters' Notes 43: 142-145.

Brasil. Ministério da Agricultura, Pecuária e Abastecimento. 2009. Roles to seed analysis. Secretaria de Defesa Agropecuária, Brasília, DF, Brazil (in Portuguese).

Burg, W.J. van der; Aartse, J.W.; Van Zwol, R.A.; Jalink, H.; Bino, R.J. 1994. Predicting tomato seedling morphology by X-ray analysis of seeds. Journal American Society for Horticultural Science 119: 258-263.

Castellani, E.D.; Damião-Filho, C.F.; Aguiar, I.B. 2001. Morphological characterization of fruits and seeds in Xylopia (Annonaceae) arboreal species. Revista Brasileira de Sementes 23: 205-211 (in Portuguese, with abstract in English).

Haig, D.; Westoby, M. 1991. Seed size, pollination costs and angiosperm success. Evolutionary Ecology 5: 231-247.

Hendrix, S.D. 1984. Variation in seed weight and its effects on germination in Pastinaca sativa L. (Umbelliferae). American Journal of Botany 91: 795-802.

Table 1 - Percentage and speed index (SI) of the emergence of seedlings and formation of normal seedlings of Xylopia aromatica, according to seed weight category.

\begin{tabular}{ccccc}
\hline \multirow{2}{*}{ Treatment } & \multicolumn{2}{c}{ Seedling emergence } & \multicolumn{2}{c}{ Normal seedling } \\
\cline { 2 - 5 } \cline { 2 - 4 } & $64 \pm 4.9 \mathrm{ab}$ & $0.392 \pm 0.03 \mathrm{ab}$ & & $0.183 \pm 0.02 \mathrm{ab}$ \\
\hline VLS & $54 \pm 11.5 \mathrm{~b}$ & $0.350 \pm 0.07 \mathrm{~b}$ & $25 \pm 9.6 \mathrm{~b}$ & $0.115 \pm 0.04 \mathrm{~b}$ \\
LS & $66 \pm 2.6 \mathrm{ab}$ & $0.407 \pm 0.02 \mathrm{ab}$ & $40 \pm 4.3 \mathrm{ab}$ & $0.166 \pm 0.01 \mathrm{ab}$ \\
HS & $78 \pm 8.7 \mathrm{a}$ & $0.511 \pm 0.05 \mathrm{a}$ & $49 \pm 7.5 \mathrm{a}$ & $0.214 \pm 0.03 \mathrm{a}$ \\
\hline
\end{tabular}

The value $( \pm)$ after each mean is the standard error. Values followed by the same letter within each column are not different (LSD test, $p<0.05) . \mathrm{S}=$ seeds which sank; VLS = very light seeds; LS = light seeds; HS = heavy seeds. 
Gonzalez, J.E. 1993. Effect of seed size on germination and seedling vigor of Virola koschnyi Warb. Forest Ecology and Management 57: 275-281.

Khan, M.L. 2004. Effects of seed mass on seedling success in Artocarpus heterophyllus L., a tropical tree species of north-east India. Acta Oecologica 25: 103-110.

Khan, M.L.; Shankar, U. 2001. Effect of seed weight, light and substratum microsite on germination and seedling growth of Quecus semiserrata Roxb. Tropical Ecology 42: 117-125.

Lobo, M.; Delgado, O.; Cartagena, J.R.; Fernández, E.; Medina, C.I. 2007. Categorization of germination and dormancy of cherimoya (Annona cherimola L.) and soursop (Annona muricata L.) seeds as a support for germplasm conservation programs. Agronomía Colombiana 25: 231244 (in Spanish, with abstract in English).

Machado, C.F.; Cicero, S.M. 2003. "Aroeira-branca" [Lithraea molleoides (Vell.) Engl. - Annacardiaceae] seed quality evaluation by the X-ray test. Scientia Agricola 60: 393-397.

Maguire, J.D. 1962. Speed of germination: aid in selection and evaluation for seedling emergence and vigour. Crop Science 2: 176-177.

Maroni, B.C.; Stasi, L.C.; Machado, S.R. 2006. Medicinal Plants of the Open Pasture of Botucatu: Illustrated Guide. UNESP, São Paulo, SP, Brazil (in Portuguese).

Moegenburg, S.M. 1996. Sabal palmetto seed size: causes of variation, choices of predators, and consequences for seedlings. Oecologia 106: 539-543.

Mondo, V.H.V.; Brancalion, P.H.S.; Garcia, D.C.; Ludwig, M.P.; Santos, V.J. 2008. Germination test of seeds of Parapiptadenia rigida (Benth.) Brenan (Fabaceae). Revista Brasileira de Sementes 30: 177-183 (in Portuguese, with abstract in English).

Parker, W.; Noland, T.L.; Morneault, A.E. 2006. The effects of seed mass on germination, seedling emergence, and early seedling growth of eastern white pine (Pinus strobus L.). New Forest 32: 33-49.

Perioto, N.W. 1997. Emergence of Bephratelloides sp. (Hymenoptera: Eurytomidae) from seeds collected in dregs of Xylopia aromatica (Annonaceae). Arquivos do Instituto Biológico 64: 135-137 (in Portuguese, with abstract in English).

Piña-Rodrigues, F.C.M.; Santos, N.R.F. 1988. Tetrazolium test. p. 91-100. In: Piña-Rodrigues, F.C.M. (coord.). Handbook of forest seed analysis. Cargill, Campinas, SP, Brazil (in Portuguese).

Pupim, T.L.; Novembre, A.D.L.C.; Carvalho, M.L.; Cicero, S.M. 2008. Using X-ray test to evaluate the quality of Embaúba seeds (Cecropia pachystachya Trec.). Revista Brasileira de Sementes 30: 28-32 (in Portuguese, with abstract in English).

Santos, S.R.G.; Aguiar, I.B. 2000. Seed germination of Sebastiania commersonia (Bill.) Smith \& Down affected by substrate and temperature regime. Revista Brasileira de Sementes 22:120-126 (in Portuguese, with abstract in English).
Santos, F.S.; Paula, R.C.; Sabonaro, D.Z.; Valadares, J. 2009. Biometric and physiological quality of Tabebuia chrysotricha (Mart. ex A. DC.) Standl. seeds from different mother trees. Scientia Forestalis 37: 163-173 (in Portuguese, with abstract in English).

Sautu, A.; Baskin, J.M.; Baskin, C.C.; Deago, J., Condit, R. 2007. Classification and ecological relationships of seed dormancy in a seasonal moist tropical forest, Panama, Central America. Seed Science Research 17: 127-140.

Schaal, B.A. 1980. Reproductive capacity and seed size in Lupinus texensis. American Journal of Botany 67: 703-709.

Secretaria do Meio Ambiente do Estado de São Paulo. [SMA]. 2003. Resolution SMA n. 47, Diário Oficial, São Paulo, November 26. 2003. (in Portuguese).

Socolowski, F.; Cicero S.M. 2008. Embryo morphological characterization by X-ray image and relation with mass and physiological quality of seeds of Tecoma stans L. Juss. Ex Kunth (Bignoniaceae). Revista Brasileira de Sementes 30: 200-208 (in Portuguese, with abstract in English).

Souza, L.A.; Reis, D.N.; Santos, J.P.; Davide, A.C. 2008. Use the X-ray in the evaluation of the quality seeds of Platypodium elegans Vog. Revista Ciência Agronômica 39: 343-347 (in Portuguese, with abstract in English).

Surles, S.E.; White, T.L.; Hodge, G.R.; Duryea, M.L. 1993. Relationships among seed weight components, seedling growth traits, and predicted field breeding values in slash pine. Canadian Journal of Forest Research 23: 1550-1556.

Susko, D.J.; Lovett-Doust, L. 2000. Patterns of seed mass variation and their effects on seedling traits in Alliaria petiolata (Brassicaceae). American Journal of Botany 87: 56-66.

Tonetti, O.A.O.; Davide, A.C.; Silva, E.A.A. 2006. Physical and physiological quality of Eremanthus erythropappus (DC.) Mac. Leish. Revista Brasileira de Sementes 28: 114-121 (in Portuguese, with abstract in English).

Upadhaya, K.; Pandey, H.N.; Law, P.S. 2007. The effect of seed mass on germination, seedling survival and growth in Prunus jenkinsii Hook.f. \& Thoms. Turk Journal of Botany 31: 31-36.

Vieira, S. 2006. Analysis of Variance (Anova). Editora Atlas, São Paulo, SP, Brazil (in Portuguese).

Received October 28, 2010

Accepted May 16, 2011 